\title{
KEPEMIMPINAN HAMBA TUHAN MENURUT MATIUS 20:25-28
}

\author{
Hannas \& Rinawaty \\ Sekolah Tinggi Teologi Internasional Harvest \\ Jl. Gunung Rinjani No. 6, Taman Himalaya, Lippo Village, Tangerang, Indonesia 15811 \\ E-mail: hannas@hits.ac.id
}

\begin{abstract}
Hannas \& Rinawaty. The leadership of God's servant raises a polemic because there are still those who think about God's servant being only servant and not being leader, however, in that opinion it is true. The researcher found a superior idea from Matthew 20:25-28 that placed God's servant not only as servant but also as leader. The method used in this research is the research developed by Walter $\mathrm{C}$. Kaiser, Jr. in the book Towards Exegetical Theology: Biblical Exegesis for Teaching and Teaching, which addresses: contextual analysis, syntactic analysis, verbal analysis, theological analysis and homiletical analysis. The researchers, after observing the principle of exegesis presented by Kaiser, Jr., found that the text of Matthew 20: 25-28 could be discussed the themes of the leadership of God's servant who studied contextual and syntactical analysis providing support for the theme. Researchers also pay attention to verbal analysis, theological analysis and homiletical analysis, the results of which support the characteristics of God's servant leadership in Matthew 20:25-28, namely: communicative, assertive, gentle, humble, serving, willing to sacrifice. Communicative is an element of character and key competencies in leadership.
\end{abstract}

Keywords: Leadership, Servant, God, Church, Jesus

\begin{abstract}
Abstrak: Hannas \& Rinawaty. Kepemimpinan hamba Tuhan menimbulkan polemik dikarenakan masih adanya pemikiran bahwa hamba Tuhan sebaiknya hanya menjadi pelayan dan bukan menjadi pemimpin, namun pernyataan tersebut tidaklah benar. Peneliti menemukan ide unggul dari Matius 20:25-28 yang menempatkan hamba Tuhan bukan hanya sebagai pelayan namun juga sebagai pemimpin. Metode yang digunakan dalam penelitian ini adalah eksegesis sebagaimana yang dikembangkan oleh Walter C. Kaiser, Jr. dalam buku Toward An Exegetical Theology: Biblical Exegesis For Preaching And Teaching, yang mencakup: analisis kontekstual, analisis sintaktikal, analisis verbal, analisis teologikal dan analisis homiletikal. Peneliti setelah memperhatikan prinsip eksegesis yang dipaparkan oleh Kaiser, Jr, menemukan bahwa teks Matius 20:25-28 dapat diberi tema kepemimpinan hamba Tuhan dikarenakan kajian analisis kontekstual dan sintaktikal memberikan dukungan terhadap tema tersebut. Peneliti juga memperhatikan analisis verbal, analisi teologikal dan analisis homiletikal, hasilnya memberikan dukungan adanya ciri-ciri dari kepemimpinan hamba Tuhan dari dalam Matius 20:25-28, yakni: komunikatif, tegas, lemah lembut, rendah hati, melayani, rela berkorban. Komunikatif merupakan unsur karakter dan kompetensi utama dalam kepemimpinan.
\end{abstract}

Kata Kunci: Kepemimpinan, Hamba, Tuhan, Gereja, Yesus

\section{PENDAHULUAN}

Kepemimpinan memiliki peran penting dalam membentuk sebuah komunitas yang utuh. Pemimpin harus dapat membawa pengikutnya menuju tujuan yang diimpikan. Seorang pemimpin juga memiliki kapasitas untuk memberikan pengaruh, menjangkau ke luar dan ke dalam organisasi. Pemimpin adalah individu yang secara signifikan mempengaruhi pikiran dan perilaku orang lain, bukan melalui paksaan, melainkan melalui persuasi (Adler dan Gundersen, 2008, p. 166). Bahaya dalam kepemimpinan terbuka lebar ketika pemimpin menjadi simbol yang diagung-agungkan, dan menggunakan kekuasaannya dengan sewenang-wenang, itulah sebabnya dibutuhkan kepemimpinan hamba Tuhan.

Dinamika kepemimpinan hamba Tuhan di dalam gereja semestinya berbeda dengan kepemimpinan sekuler. Tuhan Yesus memanggil pemimpin gereja yang penuh kerendahan hati dan memimpin dengan tujuan melayani. Perbedaan yang nyata ini ditunjukkan dengan teladan pribadi Tuhan Yesus yang datang "untuk melayani, dan bukan untuk dila- 
yani (Mat. 20:28)." Keteladan tersebut tidak semua pemimpin Kristiani dapat mengikutinya, ada pemimpin gereja yang hanya melihat jemaat sebagai sumber penghasilan, dan mengatur proses ibadah yang ada untuk memperkuat hal tersebut. Pemimpin yang demikian cenderung merasa kurang peduli terhadap kualitas kerohanian jemaat, dan tidak memiliki hubungan khusus antara para hamba Tuhan dengan jemaat. Salah satu panggilan tertinggi dari pemimpin di dalam kerajaan Allah adalah untuk menolong para jemaat untuk bertumbuh dalam imannya (Manz, 2005 , p. 98). Masalah ini patut menjadi perhatian bagi banyak pemimpin gereja, untuk menghasilkan kualitas kepemimpinan yang terbaik dalam memimpin jemaat Tuhan.

Tuhan Yesus berulang kali mengemukakan mengenai kepemimpinan yang seharusnya ditunjukkan oleh orang percaya. Ia membahas mengenai bagaimana seharusnya para pengikut-Nya menunjukkan kepemimpinan yang berbeda dengan pemimpin duniawi yang memimpin dengan keras untuk menjalankan kekuasaan. Seorang pemimpin dalam Kerajaan Allah adalah seorang hamba yang menjadi pelayan bagi yang lain (Mat. 20:25-26). Kepemimpinan seperti ini ditunjukkan dengan nyata oleh Tuhan Yesus sendiri saat Ia hidup, dan teladan tersebut adalah contoh sempurna yang perlu diikuti oleh para pemimpin yang menghamba kepada-Nya.

Setiap pelayan Tuhan atau hamba Tuhan seyogyanya melakukan kepemimpinan yang kuat dan seturut dengan Firman Tuhan. Pengajaran Firman Tuhan dan pemuridan juga merupakan tugas-tugas utama gereja yang perlu dilaksanakan dengan sebaik mungkin. Jemaat didorong untuk terlibat dalam pelayanan guna membangun Tubuh Kristus.

Ada dua rumusan masalah terkait dengan penelitian ini. Pertama, apakah definisi dari kepemimpinan hamba Tuhan. Kedua, apa sajakah yang menjadi ciri-ciri kepemimpinan hamba Tuhan jika dilihat dari hasil eksegesis menurut Matius 20:25-28. Tujuan penulisan dari penelitian ini ada dua. Pertama, untuk menjelaskan definisi kepemimpinan hamba Tuhan. Kedua, untuk menguraikan ciri-ciri kepe- mimpinan hamba Tuhan menurut Matius 20:25-28 yang dikerjakan berdasarkan hasil eksegesis.

Kebaharuan dari tulisan ini adalah peneliti melakukan analisis teks Matius 20:25-28 berdasarkan prinsip-prinsip eksegesis yang dipopulerkan oleh Walter C. Kaiser, Jr., suatu analisis yang mencakup kontekstual, sintaktikal, verbal, teologikal dan homiletikal. Peneliti menilai model eksegesis yang dikembangkan oleh Kaiser, Jr., mencakup seluruh model eksegesis yang Alkitabiah.

\section{METODE}

Peneliti menggunakan metode kualitatif (library research) dengan pendekatan hermeneutika. Sebelum judul penelitian ini ditetapkan, maka peneliti memperhatikan teks Matius 20:25-28 guna menemukan tema yang paling cocok. Pendefinisian terhadap tema dilakukan melibatkan pengertian secara etimologi dan pandangan para pakar terkait. Eksegesis terhadap teks Matius 20:25-28 dimaksudkan untuk melihat perspektif Alkitab tentang kepemimpinan hamba Tuhan menurut Matius 20:25-28. Kajian Alkitab terhadap Matius 20:25-28 dijelaskan dengan cara eksegesis, karena hanya menggunakan metode interpretasi eksegesis maka kebenaran Alkitab dapat diungkapkan secara tepat.

Metode eksegesis merupakan aplikasi dari prinsip-prinsip hermeneutik yang digunakan untuk memperoleh pengertian yang tepat mengenai teks. Istilah eksegese menurut Kamus Besar Bahasa Indonesia bermakna penjelasan atau penafsiran teks (Pena, t.t., p. 241). Virkler (1993, p.18) menjelaskan eksegesis menempatkan penafsir memperoleh pemahaman sesuai maksud penulis teks. Metode eksegesis adalah suatu aplikasi dari prinsip-prinsip hermeneutik untuk memperoleh pengertian yang tepat mengenai teks atau sebuah istilah yang diartikan sebagai suatu usaha untuk menafsirkan sesuatu. Istilah eksegese sendiri berasal dari bahasa Yunani $\varepsilon \xi \varepsilon \gamma \varepsilon o \mu \alpha l$ (exegeomai), kata depan 'eks' dalam 'eksegesis' (Yunani) berarti 'keluar dari' atau 'dari' yang menunjukkan pada ide penafsir ke dalam teks (eisegesis) yang dalam bentuk dasarnya berarti "membawa ke 
luar atau mengeluarkan". Kata bendanya sendiri berarti 'tafsiran' atau 'penjelasan' (Hayes \& Holladay, 2006, p. 1-4).

Eksegesis Alkitab adalah suatu studi tentang pernyataan (wahyu) Allah sebagaimana yang disampaikan melalui Perjanjian Lama dan Perjanjian Baru (Virkler, 1981, p. 18). Kaiser, Jr., (1988, p. 47) menjelaskan bahwa eksegesis berbeda dengan eisegesis karena eksegesis berupaya untuk menjelaskan teks Alkitab sesuai dengan maksud penulisnya bukan memaksakan pendapat seseorang agar dibenarkan oleh Alkitab. Frasa-frasa, klausa-klausa, kalimat-kalimat yang membentuk tema dari teks Alkitab dikaji dengan baik.

Langkah-langkah eksegesis yang akan dilakukan peneliti meliputi: analisis kontekstual, analisis sintaksis, analisis verbal, analisis teologikal dan analisis homiletikal. Pembahasan eksegesis kepemimpinan hamba Tuhan difokuskan pada teks Matius 20:25-28 yang akan dikaji dari berbagai terjemahan (terjemahan baru dan Yunani Perjanjian Baru).

\section{HASIL DAN PEMBAHASAN}

\section{Definisi Kepemimpinan Hamba Tuhan}

Pemimpin adalah seorang yang dipanggil, dipersiapkan, diberi kapasitas oleh Allah untuk melaksanakan misi-Nya (Mawikere, 2018, p. 65), dan melayani-Nya dengan mengabdikan diri (Katarina \& Siswanto, 2018, p. 89). Pemimpin di era yang berubah melakukan berbagai pendekatan: spiritual, edukatif, integritas, azas manfaat, humanistik (Ronda, 2019:1). Melakukan tugas kepemimpinan pada dasarnya merupakan responsnya untuk mewujudkan rencana-Nya yang dikerjakan dengan sungguh-sungguh melalui suatu pendekatan yang cocok.

Kata pemimpin merujuk kepada sosok pribadi yang menduduki suatu posisi dan melakukan pekerjaan memimpin. Kepemimpinan lebih merujuk kepada fungsi dan tanggung-jawab dari seorang pemimpin. Seorang pemimpin bisa melaksanakan tugas kepemimpinannya dengan maksimal apabila ia memiliki pengikut yang rela hati untuk dipimpin dan dituntunnya. Kouzes dan Posner (1997, p. 33), menyatakan "Saya tidak memikirkan kepemimpinan sebagai sebuah kedudukan. Saya tidak memikirkan kepemimpinan sebagai sebuah keahlian. Saya memikirkan kepemimpinan sebagai sebuah hubungan". Munroe (1993, p. 15) menyatakan kepemimpinan merupakan kemampuan untuk memimpin orang lain dengan menggunakan pengaruhnya. Wofford (2001, p. 210), menegaskan kepemimpinan adalah kemampuan untuk mempengaruhi orang lain dalam melayani atau mendedikasikan hidup guna membangun tubuh Kristus. Pemimpin yang melayani memberikan dampak yang positif bagi jemaatnya dan juga bagi lingkungan gereja karena setiap jemaat saling berlomba melakukan yang terbaik bagi Tuhan. Kepemimpinan adalah suatu proses mempengaruhi cara berpikir, perilaku, atau perkembangan orang menuju pencapaian suatu tujuan dalam kehidupan pribadi atau professional orang lain (Blanchard \& Hodges, 2007, p. 5). Keteladanan kepemimpinan akan sangat memberikan pengaruh kepada jemaat-jemaat dan juga kepada masyarakat. Penulis setelah memperhatikan pandangan para pakar di atas menyimpulkan bahwa kepemimpinan hamba Tuhan adalah cara seorang yang melayani Tuhan dalam membimbing, mendidik dan mempengaruhi jemaat untuk melakukan sesuatu sesuai dengan perintah Tuhan.

\section{Eksegesis Matius 20:25-28}

Eksegesis yang diungkapkan oleh Kaiser, Jr., mencakup lima analisis: kontekstual, sintaktikal, verbal, teologikal dan homiletikal.

\section{Analisis Kontekstual}

Analisis kontekstual adalah metode tafsiran yang mempertimbangkan hubungan antara bagian yang diberikan ke keseluruhan dari tulisan seorang penulis, untuk pemahaman yang lebih baik hasil dari pengetahuan dari keseluruhan pemikiran yang ada. Analisis konteks ini akan mengkaji hubungan dari pemikiran-pemikiran yang ada di dalam nats dan disusun menjadi satu. Kaiser, Jr (1988, p. 71) menulis bahwa konteks dimaknai sebagai suatu bagian yang 
masih memiliki hubungan yang mengikat menjadi satu kesatuan. Kata konteks dipakai untuk menunjukkan hubungan yang menyatukan bagian Alkitab yang ingin ditafsir sesuai dengan keadaan atau peristiwa yang terjadi. Prosedur eksegesis yang baik menuntut semua detail dari teks untuk dikaji dalam konteks secara utuh. Analisa konteks dalam pembahasan ini terdiri dari 4 bagian yaitu konteks seksi, konteks kitab, konteks kanon dan konteks setempat.

Konteks seksi adalah konteks bagian di mana nats ditulis, hal ini dilakukan untuk mengetahui ide pokok yang menjadi fokus dari nats kunci, biasanya berkisar beberapa ayat atau pasal sebelum dan sesudahnya. Konteks seksi dapat juga disebut sebagai "konteks dekat," dikarenakan ide pokok dari nats kunci ditemukan disekitarnya. Bila penggunaan konteks dekat tidak memberikan tafsiran yang memadai, maka digunakan konteks yang lebih jauh, seperti keseluruhan kitab, atau kitab lain yang ditulis oleh penulis yang sama, dan ini disebut "konteks jauh."

Konteks seksi dari teks Matius 20:25-28 adalah Matius 20:17-34. Teks Matius 20:17-34 menjelaskan tentang Pelayanan Yesus di Yudea 20:1734. Matius 20:17-24 secara khusus menjelaskan tentang pemberitahuan kematian dan kebangkitan Yesus. Matius 20:25-28 secara khusus mengajarkan tentang kepemimpinan hamba Tuhan, yang dicirikan dengan: komunikatif (ay. 25), tegas (ay. 26), lemah lembut (ay. 26), rendah hati (ay. 26-27), melayani (ay. 28) dan rela berkorban (ay. 28). Matius 20:2934 secara khusus menjelaskan tentang mujizat kesembuhan Ilahi.

Konteks kitab adalah konteks yang berguna untuk mengetahui atau mengindentifikasikan tujuan dari keseluruhan kitab tersebut. Kaiser, Jr. menyatakan "The book context should be possible to identify the overall purpose and plan of the book" (Kaiser, Jr., 1988, p. 71). Peneliti dalam menganalisis konteks kitab ini akan menguraikan: penulis dan latar belakang penulisan kitab, tujuan penulisan kitab, tempat dan tahun penulisan kitab, dan garis besar penulisan kitab.
Penulis Injil Matius tidak ditulis secara langsung dalam kitab ini, sebab penulis sendiri tidak menuliskan namanya, namun secara umum diterima bahwa Matius merupakan penulis kitab ini. Stamps (2008, p. 195) menyatakan penulis Injil Matius adalah Matius. Douglas (1984, p. 749) menjelaskan bahwa Matius memang tidak disebutkan dalam kitab yang pertama dari 27 kitab Perjanjian Baru, tetapi pernyataan Papias tentang rasul Matius sebagai penulis menjadi dasar kitab ini disebut Injil Matius. Kesaksian bapa-bapa gereja mula-mula sejak kirakira $130 \mathrm{M}$ juga menyatakan bahwa Injil ini ditulis oleh Matius, salah seorang murid Yesus.

Kitab Matius 9:9-13 menjelaskan bahwa Matius adalah seorang pemungut cukai yang dipanggil Yesus untuk menjadi murid-Nya. Istilah pemungut cukai adalah cercaan bagi pemungut pajak Roma, karena memungut pajak biasanya dilakukan dengan cara memeras. Orang-orang Yahudi sangat membenci anggota masyarakat yang melayani dan bekerja untuk kepentingan penjajah (Roma). Matius dalam tulisannya yang ditujukan kepada orang-orang Yahudi tidak malu menyebut dirinya sebagai pemungut cukai sebelum mengikut Yesus, sekalipun dianggap rendah. Matius memang orang yang tepat sekali untuk menulis sebuah buku tentang pengajaran dan perbuatan Yesus, karena pekerjaannya adalah pemungut cukai. Pemungut cukai adalah orang-orang yang pandai berhitung, suka mencatat dan teliti sampai pada bagian yang terkecil sekalipun. Pekerjaan sebagai pemungut cukai membiasakan Matius membuat catatan-catatan bahwa Matius memperhatikan secara saksama kepada hal-hal kecil, hal tersebut tergambar dalam Injil Matius.

Data internal menyebutkan bahwa Matius adalah salah seorang dari 12 rasul yang dipilih oleh Tuhan Yesus menjadi murid-Nya (Mat. 10:3; Mar. 3:18; Luk. 6:15; Kis. 1:13). Matius sebagai rasul tentu menjadi saksi mata dari kehidupan Yesus Kristus bahkan mendengar langsung pengajaran-pengajaran-Nya. Jadi, berdasarkan uraian di atas, maka dapat disimpulkan bahwa penulis Injil Matius adalah rasul Matius, seorang murid Tuhan Yesus Kristus. 
Stamps (2008, p. 1495-1496) menulis latar belakang ditulisnya Injil Matius: (1) membuktikan bahwa Yesus memang Mesias yang sudah lama dinantikan; (2) Yesus merupakan keturunan dari Abraham (Mat 1:1-17); (3) Yesus adalah "Anak Daud" (Mat 1:1; Mat 9:27; Mat 12:23; Mat 15:22; Mat 20:30-31; Mat 21:9,15; Mat 22:41-45); (4) Istilah "Kerajaan Sorga" digunakan sebagai ungkapan rasa hormat orang Yahudi sehingga segan menyebut nama Allah secara langsung dan (5) secara khusus menjelaskan berbagai kebiasaan Yahudi.

Latar belakang ditulisnya Injil Matius dikarenakan orang-orang percaya Yahudi sangat bergantung pada nubuatan Perjanjian Lama yang menyatakan tentang kehadiran Mesias. Injil Matius menggenapi nubuat bahwa Yesus Kristus adalah benar Mesias seperti yang dinyatakan dalam Perjanjian Lama. Yesus adalah keturunan Abraham, yang disebut sebagai "Anak Daud" (Mat. 1:1-17; 2 Sam. 7:12-13). Packer, Tenney, \& White, Jr., (1995, p. 159) menulis bahwa Injil Matius menekankan Yesus adalah Mesias yang dijanjikan, yang datang untuk menebus seluruh umat manusia. Jadi latar belakang ditulisnya Injil Matius dikarenakan adanya orangorang percaya Yahudi yang menantikan kedatangan Mesias yang kemudian digenapi dalam Yesus Kristus sebagai keturunan Anak Daud.

Stamps (2008, p. 1496) menjelaskan tujuan ditulisnya Injil Matius mencakup: kehidupan Yesus, Yesus adalah Mesias dan merepresentasikan Kerajaan Allah. Penjelasan Stamps menunjukkan bahwa tujuan ditulisnya Injil Matius adalah untuk membuktikan bahwa Yesus adalah Anak Allah, Mesias seperti yang dinubuatkan dalam Perjanjian Lama dan akan menyatakan kerajaan seribu tahun damai di bumi. Enns (2003, p. 97) memberikan pernyataan terkait bahwa Kerajaaan seribu tahun membuktikan Yesus adalah Mesias dan didirikan pada saat Kedatangan-Nya Kedua. Jadi jelaslah bahwa baik Stamps maupun Enns sama-sama menyetujui tujuan ditulisnya Injil Matius adalah untuk menjelaskan bahwa Yesus Kristus adalah Mesias, Anak Allah sebagaimana yang dinubuatkan dalam Perjanjian Lama.
Kristus yang sama juga akan mendirikan kerajaan millenium di bumi.

Nuansa keyahudian yang tercermin dalam Injil Matius menunjukkan bahwa kitab ini ditulis di Palestina atau Antiokhia, Siria. Beberapa alasan yang menguatkan hal ini adalah kutipan-kutipan Injil dalam karya para penulis gereja yang pertama seperti Papias dan Ignatius sangat menyerupai ayat-ayat dalam Injil Matius, dan ini menunjukkan bahwa Injil Matius ini mungkin merupakan pilihan jemaat Siria Yahudi.

Mengenai tahun penulisan kitab ini, beberapa pandangan mengatakan bahwa berdasarkan karakteristik Yahudi di dalam kitab ini kemungkinan besar kitab Matius ditulis pada masa gereja yang mula-mula, yaitu sekitar tahun $50 \mathrm{M}$, di mana anggota gereja pada umumnya adalah orang-orang Yahudi dan Injil hanya diberitakan kepada orang-orang Yahudi saja. Selain pandangan di atas, ada juga pandangan lain yang menyatakan bahwa kitab Matius ditulis sekitar tahun 60-an TM (Stamps, 2008, p. 195). Jika Injil Matius bersumber dari Injil Markus, dan jika Injil Markus ditulis sesudah Petrus meninggal (65 M), maka Injil Matius ditulis setelah itu, hal lain yang mendukung pandangan ini adalah hubungan Matius dengan kejatuhan Yerusalem pada tahun 70. Kebanyakan ahli berpendapat karena Matius menyinggung jatuhnya Yerusalem secara tidak langsung. Injil Matius tentu ditulis sesudah tahun 70 . Jadi berdasarkan pemaparan di atas, dapat disimpulkan bahwa Injil Matius ditulis sekitar tahun 60-70 M di Antiokhia, Siria.

Injil Matius secara keseluruhan mengungkapkan tentang Yesus Kristus sebagai penggenapan nubuatan dalam Perjanjian Lama tentang Mesias dan Raja yang dijanjikan kepada umat pilihan Allah. Pasal pertama dari Injil Matius dimulai dengan silsilah Yesus Kristus yang menjelaskan garis keturunan Raja Daud, Salomo dan seterusnya. Judul silsilah disebut "silsilah Yesus Kristus, anak Daud, anak Abraham," karena janji tentang Mesias yang akan menjadi berkat bagi segala bangsa secara eksplisit disam- 
paikan kepada Abraham dan selanjutnya kepada Daud.

Garis besar Injil dapat dijelaskan sebagai berikut. Matius 1:1-2:23 menjelaskan tentang kelahiran dan masa kanak-kanak Kristus. Matius 3:1-4:25 menjelaskan tentang baptisan dan pencobaan Kristus. Matius 5:1-7:29 menjelaskan tentang khotbah di Bukit. Matius 8:1-9:38 menjelaskan tentang perbuatanperbuatan besar menyertai pelayanan Yesus. Matius 10:1-11:30 menjelaskan tentang Yesus mendelegasikan tugas pelayanan terhadap murid-muridNya. Matius 12:1-13:58 menjelaskan tentang kerajaan Allah. Matius 14:1-17:23 menjelaskan tentang pelayanan Yesus di wilayah Kaisarea, Filipi. Matius 17:24-18: 35 menjelaskan ten-tang pelayanan Yesus di Kapernaum. Matius 19:1-20:16 menjelaskan tentang pelayanan Yesus di daerah seberang Sungai Yordan (Perea). Matius 20:17-34 menjelaskan tentang pelayanan Yesus di Yudea: pemberitahuan kematian dan kebangkitan Yesus (20:17-24), pengajaran tentang kepemimpinan hamba Tuhan (20:25-28), mujizat kesembuhan Ilahi (20:29-34). Matius 21:1-25:46 menjelaskan tentang pelayanan Yesus di Yerusalem. Matius 26:1-27:66 menjelaskan tentang kesengsaraan Yesus Kristus. Matius 28:1-20 menjelaskan tentang Kebangkitan Yesus Kristus. Jadi jelaslah melalui garis besar di atas tergambar Matius 20:25-28 adalah benar terkait dengan kepemimpinan hamba Tuhan.

Crampton (2000, p. 48-50) menjelaskan kanon diinspirasikan oleh Tuhan, kebenaran yang bersifat obyektif yang dituangkan dalam kitab suci. Orang-orang Kristen mula-mula tidak memiliki kanon Perjanjian Baru. Setelah kenaikan Yesus ke sorga, ada sekitar 20-30 tahun berlalu di mana pengajaran dan cerita perbuatan Yesus diberitakan dari mulut ke mulut oleh para rasul dan orang-orang percaya lainnya dan tidak sebuah kitab pun ditulis pada waktu itu. Lalu mulai muncullah beberapa tulisan. Yakobus mungkin menulis sebelum tahun 50 A.D. Begitu juga dengan Paulus menuliskan surat Tesalonika. Lalu berangsur-angsur surat-surat dan kitab-kitab lain dituliskan. Kitab-kitab Injil perlu dituliskan karena gereja mula-mula menghargai dan mengambil langkah untuk memelihara pengajaran Yesus.

Injil Matius merupakan bagian dari kitab Perjanjian Baru, yang terdiri dari 27 kitab digolongkan sebagai kitab yang kanonik. Injil Matius masuk dalam 24 kitab pengkanonan Ireneus (130200 BC); dalam 22 kitab pengkanonan Muratorian (170-210 BC); dalam 22 kitab yang tidak dipersoalkan dalam pengkanonan Eusebius (260-340 BC); dalam 27 kitab pengkanonan Athanasius (367 BC); dan dalam 27 kitab pengkanonan tahun 397 yang berlaku sampai sekarang (Douglas, 1984, p. 173). Kanonisasi adalah suatu proses yang panjang. Sekalipun tampaknya umat Allah memainkan peranan yang penting dalam proses kanonisasi tersebut, namun, hal yang cukup mengagetkan, dalam sejarah tidak ada suatu saat atau suatu peristiwa di mana kumpulan kitab-kitab ini ditentukan atau diproklamirkan sebagai kanon. Jadi bukan gereja yang "menentukan" atau "menciptakan" kanon Alkitab, melainkan gereja hanya mengenali dan menerima kanon tersebut.

27 kitab dalam Perjanjian Baru didapati otoritatif karena memiliki intrinsic worth dan otoritas yang jelas pada dirinya sendiri, bukan karena kitabkitab ini "ditentukan" otoritatif oleh kewenangan yang lain (gereja). Jadi, otoritas Alkitab bersifat intrinsik dan hanya perlu dikenali oleh gereja mulamula. Injil Matius merupakan salah satu dari 27 kitab dalam Perjanjian Baru. Oleh karena itu, Injil Matius adalah firman Allah yang otoritasnya tidak diragukan.

Ryrie (1991, p. 147) menuliskan dengan baik bahwa kanon artinya alat ukur untuk suatu tindakan, yang didasarkan pada kitab-kitab yang dianggap berwibawa. Jadi, Injil Matius yang tergolong kanon, menjadi ukuran kehidupan dan layak dipakai sebagai kajian dari Alkitab, khususnya yang berkaitan dengan kepemimpinan hamba Tuhan dalam Matius 20:25-28.

Alamat tujuan penulisan Injil Matius ini, baik dari pertimbangan isinya maupun bukti dari para penulis kuno, adalah kepada bangsa Yahudi di zaman itu. Perhatian penggenapan nubuatan sangat menjadi perhatian di kalangan bangsa Yahudi, kare- 
na itu penulis yang dianggap tepat adalah rasul Matius. Isi Injil Matius adalah pilihan secara spesifik pada bagian-bagian kisah Juruselamat; menggeser pengharapan-pengharapan yang keliru tentang suatu kerajaan dunia; mengurangi Injil; dan mempersiapkan mereka untuk masuknya bangsa-bangsa ke dalam Gereja. Jadi konteks setempat menunjuk pada hidup keagamaan Yahudi yang menyimpang dari harapan-harapan dan nubuatan-nubuatan Perjanjian Lama, terutama mengubah perhatian mereka pada bangsa sendiri dan memberi perhatian keluar sebagai perintah dari Tuhan terhadap bangsa-bangsa.

Uraian dari analisis kontekstual sebagaimana yang telah dijelaskan sebelumnya menunjukkan bahwa kitab ini ditulis oleh Matius, sekitar tahun 60 sampai 70, ketika Matius berada di Palestina atau Antiokhia di Siria. Tujuan Matius menulis kitab ini adalah untuk meyakinkan pembacanya bahwa Yesus adalah Anak Allah yang dinubuatkan oleh nabi-nabi Perjanjian Lama, yang sudah lama dinantikan oleh orang-orang Israel dan menyatakan akan adanya millenium. Injil Matius ini secara keseluruhan mengungkapkan tentang Yesus Kristus sebagai penggenapan nubuatan Mesias dalam Perjanjian Lama dan Raja yang dijanjikan kepada umat pilihan Allah.

\section{Analisis Sintaksis}

Pengkajian terhadap teks Matius 20:25-28 dilakukan dengan menggunakan analisis sintaksis guna memperoleh makna yang dimaksudkan oleh teks tersebut. Kaiser, Jr., (1988, p. 104) mengindentifikasikan sintaksis, yakni: tema proposisi, hubungan frasa-frasa dengan tema proposisi, hubungan klausaklausa dengan tema proposisi dan hubungan kalimat-kalimat dengan tema proposisi. Kaiser, Jr (1988, p. 100) menulis tema proposisi merupakan inti dari setiap paragraf ataupun yang akan diteliti. Jadi tema proposisi dari teks Matius 20:25-28 adalah kepemimpinan hamba Tuhan.

Teks Matius 20:25-28 memiliki frasa-frasa yang berhubungan dengan tema proposisi kepemimpinan hamba Tuhan. Frasa adalah "Gabungan dua kata atau lebih yang bersifat nonpredikatif (tidak berkaitan dengan predikat)" (Pena, t. t., p. 20102011). Adapun frasa-frasa yang mendukung tema proposisi kepemimpinan hamba Tuhan menurut Matius 20:25-28 adalah sebagai berikut.

Frasa pertama: "Tangan Besi” (ay. 25). Frasa ini menunjuk kepada cara seorang pemimpin pemerintahan dalam menjalankan tugasnya untuk memimpin rakyatnya. Para pemimpin memimpin tidak dengan lemah lembut tetapi dengan kekuasaan yang sewenang-wenang, kejam tanpa ada rasa kasihan ataupun kasih.

Frasa kedua: "Tidaklah demikian antara kamu" (ay. 26). Frasa ini menunjuk kepada murid-murid Tuhan Yesus. Kepemimpinan para murid-murid berbeda dengan kepemimpinan pemerintahan dalam memimpin bangsa/rakyatnya. Yesus mengatakan bahwa kepemimpinan murid-murid harus melayani dan bukan dilayani.

Frasa ketiga: "Menjadi besar" (ay. 26). Frasa ini menunjuk kepada murid-murid besar jika ingin menjadi besar atau ingin menjadi pemimpin haruslah memiliki sikap rendah hati dan rela berkorban seperti seorang pelayan. Hal ini sangat berbeda dengan apa yang dipikirkan para murid yang masih berpikir memimpin seperti pemimpin atau pemerintahan duniawi.

Frasa keempat: "Menjadi terkemuka" (ay. 27). Frasa ini menekankan kepada para pelayan Tuhan agar segera memperlengkapi jemaat dengan pengetahuan yang benar mengenai Firman Allah sehingga jemaat-jemaat mampu menghadapi pengajaran-pengajaran yang tidak benar, licik atau sesat. Matius menekankan pada suratnya ini agar pengajaran yang benar diberikan kepada jemaat.

Frasa kelima: "Anak Manusia” (ay. 28). Frasa ini mengingatkan kepada pemimpin-pemimpin agar tidak berhenti memberikan pengajaran sehingga jemaat-jemaat mengalami kepenuhan di dalam Yesus Kristus.

Frasa keenam: "Menjadi tebusan bagi banyak orang" (ay. 28). Frasa ini, menjelaskan bahwa ketika para pelayan Tuhan (pemimpin-pemimpin) dan jemaat secara bersama-sama agar menyadari bahwa 
kehadiran Kristus di bumi adalah menjadi penebus dosa bagi setiap orang. Jadi, melalui frasa-frasa di atas dapat disimpulkan bahwa terdapat hubungan frasa-frasa dengan tema proposisi yaitu kepemimpinan hamba Tuhan yang menunjukkan sikap dari para hamba Tuhan dalam memimpin jemaat yang sudah dipercayakan kepadanya.

Kaiser, Jr., (1988, p. 97) menulis klausa adalah sekelompok kata yang memiliki subyek dan predikat (kata kerja), serta berpotensi menjadi kalimat (http://pusatbahasa.kemdiknas.go.id/kbbi/). Teks Matius 20:25-28 memiliki klausa-klausa yang berhubungan dengan tema proposisi kepemimpinan hamba Tuhan.

Klausa pertama: "Tetapi Yesus memanggil mereka lalu berkata" (ay. 25) Klausa ini menyatakan bahwa Tuhan Yesus juga menyediakan waktu untuk berkumpul, berkomunikasi dengan para murid-Nya, untuk bersekutu, yang selanjutnya digunakan untuk memberikan pengajaran-pengajaran. Pengajaran yang diberikan-Nya untuk mempersiapkan dan membekali para murid agar siap untuk melayani.

Klausa kedua: "Kamu tahu, bahwa pemerintah-pemerintah bangsa-bangsa memerintah rakyatnya dengan tangan besi” (ay. 25). Klausa ini menjelaskan bahwa Tuhan Yesus memberitahukan kepada para murid-Nya bahwa gaya kepemimpinan para pemerintah dan pembesar-pembesar memimpin dengan mengandalkan kekuasaan, keras dan tanpa belas kasihan.

Klausa ketiga: "pembesar-pembesar menjalankan kuasanya dengan keras atas mereka" (ay. 25). Klausa ini menjelaskan bahwa Tuhan Yesus memberitahukan kepada para murid-Nya bahwa gaya kepemimpinan para pembesar yang menjalankan tugas kepemimpinannya mengandalkan kekuasaan dan bertindak dengan keras (diktator).

Klausa keempat: "Barangsiapa ingin menjadi besar di antara kamu, hendaklah ia menjadi pelayanmu" (ay. 26). Klausa ini menunjukkan bahwa Tuhan Yesus mengatakan kepada para murid-Nya suatu hal yang bertolak belakang dengan kepemimpinan dunia (pemerintahan dan pembesar). Jika ingin menjadi besar, maka harus melayani bukan menguasai dengan otoriter.

Klausa kelima: "barangsiapa ingin menjadi terkemuka di antara kamu, hendaklah ia menjadi hambamu" (ay. 27). Klausa ini, menyatakan bahwa Tuhan Yesus tetap menekankan sikap hidup sebagai pemimpin rohani, yang sangat berbeda dengan kepemimpinan duniawi.

Klausa keenam: "sama seperti Anak Manusia datang bukan untuk dilayani, melainkan untuk melayani, dan untuk memberikan nyawa-Nya menjadi tebusan bagi banyak orang" (ay. 28). Klausa ini menjelaskan bahwa Tuhan Yesus menyatakan diriNya dan tujuan dari kedatangan-Nya agar para murid juga mengikuti hal yang telah dilakukan-Nya. Jadi, dari uraian di atas maka dapat disimpulkan bahwa terdapat hubungan klausa-klausa dengan tema proposisi kepemimpinan hamba Tuhan menu-rut Matius 20:25-28 yaitu sikap dari seorang pemim-pin rohani yang bertolak belakang dengan sikap pemimpin dari pemerintahan dan pembesar-pembesar yang memimpin dengan tangan besi dan kuasa yang diktator berbeda dengan sikap pemimpin rohani yang memimpin dengan lemah lembut, tegas, melayani dan rela berkorban.

Kalimat adalah perkataan, ujaran yang utuh yang mengungkapkan konsep pikiran dan perasaan, (Pena, t. t., p. 384) biasanya diakhiri dengan tanda titik ( . ). Matius 20:25-28 mengandung kalimatkalimat yang berhubungan dengan kepemimpinan hamba Tuhan. Kalimat-kalimat yang diambil berhubungan dengan tema proposisi adalah sebagai berikut.

Kalimat pertama, "Tetapi Yesus memanggil mereka lalu berkata: "Kamu tahu, bahwa pemerintah-pemerintah bangsa-bangsa memerintah rakyatnya dengan tangan besi dan pembesar-pembesar menjalankan kuasanya dengan keras atas mereka" (ay. 25). Kalimat tersebut menjelaskan bahwa Tuhan Yesus mengajarkan kepada para murid-Nya gaya kepemimpinan duniawi (pemerintah dan pembesar) menggunakan tangan besi dan kekuasaan yang keras. Para pemimpin tersebut melaksanakan kepemimpinannya 
berdasarkan kekuasaan yang dimilikinya dan sewenang-wenang tanpa belas kasih.

Kalimat kedua, "Tidaklah demikian di antara kamu. Barangsiapa ingin menjadi besar di antara kamu, hendaklah ia menjadi pelayanmu, dan barangsiapa ingin menjadi terkemuka di antara kamu, hendaklah ia menjadi hambamu; sama seperti Anak Manusia datang bukan untuk dilayani, melainkan untuk melayani dan untuk memberikan nyawa-Nya menjadi tebusan bagi banyak orang" (ay. 26-28). Kalimat tersebut menjelaskan bahwa Tuhan Yesus mengingatkan kembali kepada para murid-Nya sikap atau karakter dari seorang pemimpin. Pemimpin yang dipikirkan oleh para murid sangat berbeda dengan yang diajarkan Tuhan Yesus. Tuhan Yesus mengajarkan bahwa kepemimpinan hamba Tuhan haruslah lemah lembut, rendah hati, melayani dan rela berkorban. Yesus datang ke dalam dunia bertujuan untuk menjadi Juruselamat melalui kepemimpinan hamba. Jadi berdasarkan analisis sintaksis di atas yang dilihat secara hubungan frasa-frasa, klausaklausa dan kalimat-kalimat dengan tema proposis, maka terdapat hubungan frasa, klausa dan kalimatkalimat dengan tema proposisi pada Matius 20:25-28.

\section{Analisis Verbal}

Kata verbal berasal dari bahasa latin yaitu "verbum" yang artinya kata, dan bila diteliti lebih jauh maka verbal adalah kelas kata yang menyatakan suatu tindakan, keberadaan, pengalaman, atau pengertian dinamis lainnya. Jenis kata ini biasanya menjadi predikat atau kata kerja dalam suatu frasa atau kalimat. Virkler (1993, p. 94) menulis bahwa analisis verbal mempelajari arti dari kata-kata (lexicology) dan cara kata-kata tersebut dikombinasikan (syntax), sehingga ditemukan makna yang benar sesuai dengan maksud penulis kitab. Peneliti akan melakukan analisis verbal meliputi: leksikal, gramatikal, dan historikal.

\section{Leksikal}

Douglas Stuart menyatakan, "kata leksikal berasal dari kata leksikon yang memiliki arti kamus, yang merupakan sumber-sumber informasi yang ber- harga mengenai kata-kata yang tercantum di dalamnya" (Stuart, 1994, p. 158). Jadi analisis leksikal adalah analisis terhadap arti kata di dalam bahasa asli. Maksudnya adalah agar dapat menemukan arti yang sebenarnya dan dapat mengungkapkan arti yang terkandung di dalam tiap-tiap kata tersebut. Analisis leksikal yang dibahas peneliti mencakup istilah: memanggil (proskale-samenos), tangan besi (katakurieuousin), dengan keras (kate-xousiazousin), menjadi pelayanmu (estai humōn diakonos), menjadi hambamu (estai humōn doulos), untuk melayani (diakonēsai), memberikan nyawa-Nya (dosnai ton psuchen).

Istilah "memanggil" dalam ayat 25 yang digunakan oleh Lembaga Alkitab Indonesia (LAI), dalam bahasa Yunani menggunakan kata $\pi \rho o \sigma \kappa \alpha-$ $\lambda \varepsilon \sigma a ́ \mu \varepsilon v o \varsigma$ (proskalesamenos) dari akar kata $\pi \rho o \sigma \kappa \alpha-$

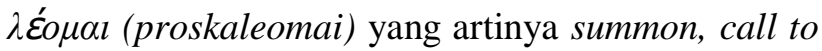
oneself, invite (Bauer's \& Gingrich, 1958, p. 171).

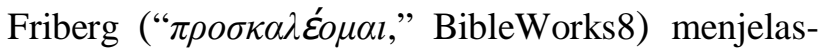

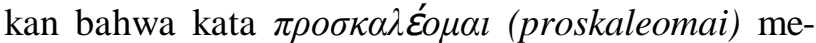
miliki arti secara literal yaitu panggilan untuk diri sendiri atau memanggil dan secara figuratif yaitu panggilan Ilahi untuk iman dan panggilan keselamatan, mengundang secara khusus, panggilan untuk tugas khusus. Jadi dapat diberi kesimpulan bahwa is-

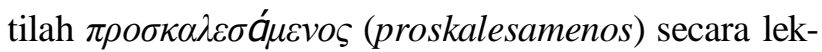
sikal dalam Matius 20:25 dapat diartikan panggilan Ilahi untuk tugas khusus.

Istilah "tangan besi" dalam ayat 25 yang digunakan oleh LAI, dalam bahasa Yunani menggu-

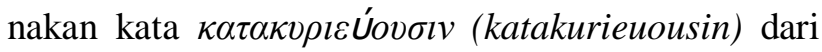

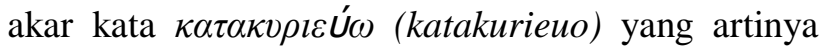
become master, gain dominion over, subdue (menjadi tuan, memperoleh kekuasaan atas, menundukkan) (Bauer's, Arndt, \& Gingrich, 1958, p. 102). Louw-Nida mengartikan kata ini adalah "to rule or reign over, with the implication in some contexts of 'lording it over' - 'to rule, to govern, to reign over"

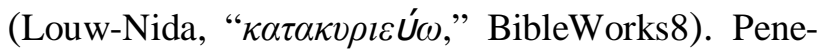
kanan Louw-Nida adalah untuk merajai atau memerintah dengan penerapan menjadi tuan atas sesuatu. 


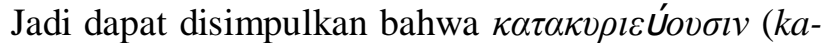
takurieuousin) secara leksikal dalam Matius 20:25 dapat diartikan menjadi tuan dengan melakukan kekuasaan yang berlebihan.

Istilah "dengan keras" dalam ayat 25 yang digunakan oleh LAI, dalam bahasa Yunani meng-

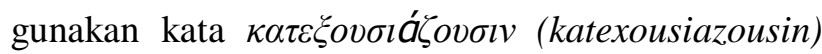
dari akar kata $\kappa \alpha \tau \varepsilon \xi o v \sigma ı a ́ \zeta \omega ~(k a t e x o u s i a z o)$ yang artinya exercise authority over, domineer (menggunakan wewenang berlebihan, menguasai) (Bauer's, Arndt, \& Gingrich, 1958, p. 102). Friberg mengartikan $\kappa \alpha \tau \varepsilon \xi o v \sigma ı a ́ \zeta \omega ~(k a t e x o u s i a z o)$ adalah kepemilikan dalam pelaksanaan otoritas yang bersifat tirani

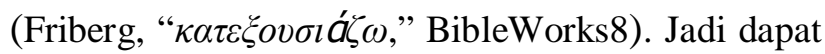
diberi kesimpulan bahwa istilah $\kappa \alpha \tau \varepsilon \xi o v \sigma ı a ́ \zeta o v \sigma ı v$ (katexousiazousin) secara leksikal dalam Matius 20: 25 dapat diartikan menggunakan wewenang berlebihan atau bersifat tirani.

Istilah "menjadi pelayanmu" dalam ayat 26 yang digunakan oleh Lembaga Alkitab Indonesia, dalam bahasa Yunani menggunakan kalimat है $\sigma \tau \alpha l$

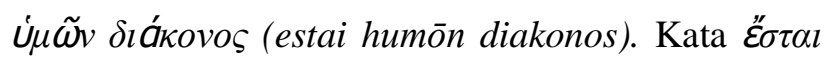
(estai) dari akar kata cípí (eimi) yang artinya be, exist, be present, stay, reside (menjadi, ada, hadir, tinggal, berada), (Bauer's, Arndt, \& Gingrich, 1958,

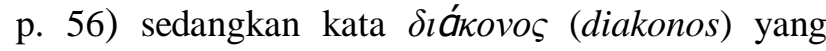
merupakan akar kata artinya pelayan (Mat. 20:26; 22:13; Mark. 9:35; Yoh. 2: 5, 9; Rm. 13:4; Gal. 2: 17), pelayan Allah atau Kristus (2Kor. 6: 4; 11:23; Ef. 6:21; Kol. 1:23, 25; 1Tim. 4:6), diaken (Bauer's, Arndt, \& Gingrich, 1958, p. 46).

Jadi dapat diberi kesimpulan bahwa istilah

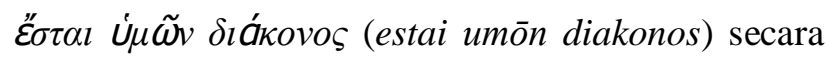
leksikal dalam Matius 20:26 dapat diartikan menjadi hamba, pelayan atau orang yang menolong untuk melayani.

Istilah "menjadi hambamu" dalam ayat 27 yang digunakan oleh Lembaga Alkitab Indonesia, dalam bahasa Yunani menggunakan kata हैं $\tau \alpha \iota ~ \dot{\cup} \mu \tilde{\omega} v$

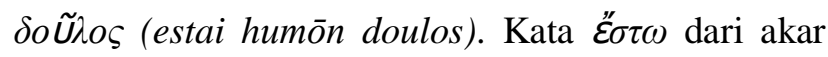
kata síuí (eimi) yang artinya be, exist, be present, stay, reside (menjadi, ada, hadir, tinggal, berada)
(Bauer's, Arndt, \& Gingrich, 1958, p. 56). LouwNida mengartikan "to possess certain characteristics, whether inherent or transitory - to be,' (LouwNida, “eílí," BibleWorks8)." Jadi istilah है $\sigma \tau \alpha l$ (estai) dalam bagian ini diartikan dengan untuk

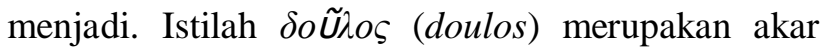
kata yang artinya slavish, servile (seperti budak belian, bersifat merendahkan diri) (Bauer's, Arndt, \& Gingrich, 1958, p. 51). Friberg mengartikan kata

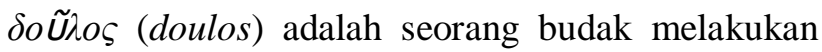
pelayanan budak; dalam arti kiasan adalah taat yang tidak perlu diragukan lagi (Friberg, " $\delta o \tilde{u} \lambda o \varsigma, "$ BibleWorks8). Jadi dapat diberi kesimpulan bahwa

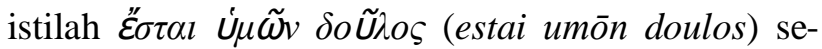
cara leksikal dalam Matius 20:27 dapat diartikan untuk menjadi budak belian yang merendahkan diri untuk melakukan pelayanan dengan penuh ketaatan.

Istilah "untuk melayani" dalam ayat 28 yang digunakan oleh LAI, dalam bahasa Yunani menggunakan kata $\delta \iota \alpha \kappa o v \tilde{\eta} \sigma \alpha l$ (diakonēsai) dari akar kata

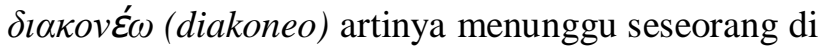
meja makan, pada umunya untuk melayani atau melayani sebagai diaken (Bauer's, Arndt, \& Gingrich, 1958, p. 45). Hal yang sama dijelaskan oleh LiddelScott yaitu "to minister, serve, do service" (Liddell-

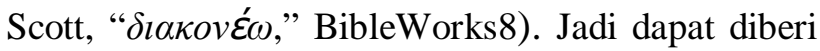

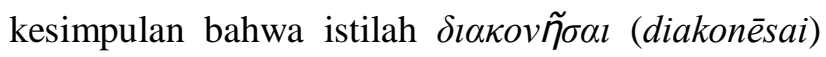
secara leksikal dalam Matius 20:28 dapat diartikan untuk melayani.

Istilah "memberikan nyawa-Nya" dalam ayat 28 yang digunakan oleh LAI, dalam bahasa $\mathrm{Yu}$ -

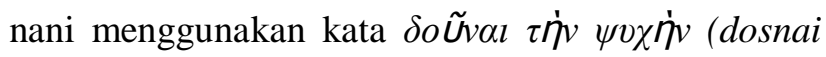
ton psuchen). Istilah memberikan $\delta o \tilde{v} \alpha l$ (dosnai) dari akar kata $\delta i \delta \omega \mu$ (didomi) yang artinya give (Bauer's, Arndt, \& Gingrich, 1958, p. 48). Friberg mengartikan kata $\delta i \delta \omega \mu \iota$ (didomi) sebagai tindakan memberi, tapi dalam menjelaskan artinya lebih jauh harus melihat konteks yang digunakan untuk menjelaskan kata ini. Khusus dalam Matius 20:28, kata ini diartikan dengan sebagai bentuk pemberian dengan sikap menyerah (Friberg, “ $\delta \prime \delta \omega \mu l$," BibleWorks 
8). Jadi dapat diberi kesimpulan bahwa istilah

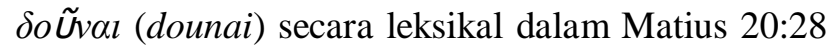
dapat diartikan memberikan dengan sikap menyerah. Yesus menyerahkan atau memberikan nyawa-Nya untuk menjadi tebusan.

\section{Gramatikal}

Analisis gramatikal merupakan analisa yang menjelaskan tentang analisis golongan kata berdasarkan petikan teks Alkitab. Kata-kata yang ditelaah untuk analisis gramatikal selalu dilihat berdasarkan kaitannya dengan ayat atau konteks kalimat yang melingkupinya (Dana, \& Mantey, 1957, p. 150). Analisis ini akan membahas secara gramatikal istilah: memanggil (proskalesamenos), tangan besi ( $k a-$ takurieuousin), dengan keras (kate-xousiazousin), menjadi pelayanmu (estai humōn diakonos), menjadi hambamu (estai humōn doulos), untuk melayani (diakonēsai), memberikan nyawa-Nya (dosnai ton psuchen).

Istilah "memanggil" dalam bahasa Yunani menggunakan kata $\pi \rho \sigma \sigma \kappa \alpha \lambda \varepsilon \sigma a ́ \mu \varepsilon v o \varsigma$ (proskalesamenos) merupakan bentuk verb participle aorist middle nominative masculine singular. Partisip memiliki fungsi dan ciri yang sama dengan kata kerja dan kata sifat (Suawa, 2009, p. 145). Kata memanggil berfungsi sebagai kata kerja yaitu memberi panggilan dan berfungsi sebagai kata sifat yaitu Yesus yang memanggil. Tindas (2006, p. 55) menjelaskan "sebagai kata kerja partisip mempunyai arah dan tense serta dapat berfungsi sebagai kata keterangan." Keterangan terkait dengan kata kerja pokok berhubungan dengan waktu. Arah dalam bagian ini adalah middle dan tense-nya adalah aorist. Tindas (2006, p. 55). Kata kerja pokok dalam klausa "Tetapi Yesus memanggil mereka lalu berkata: "Kamu tahu, bahwa pemerintah-pemerintah bangsa-bangsa memerintah rakyatnya dengan tangan besi" dari $\mathrm{Yu}$ nani Perjanjian Baru, $\dot{o} \delta \dot{\varepsilon}$ 'I

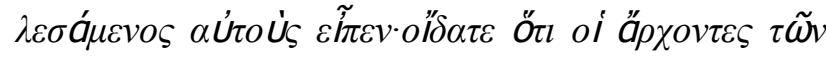

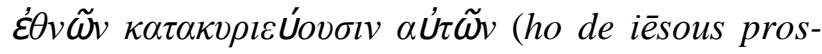
kalesamenos autous eipen. oidate hoti hoi archontes tōn ethnōn katakurieuousin autōn) adalah "meme- rintah." Istilah memerintah dalam Yunani Perjanjian

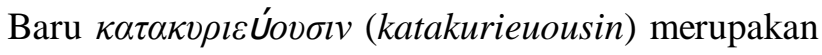
bentuk verb indicative present active $3 r d$ person

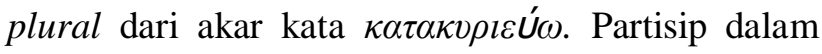
klausa ini menerangkan kapan Yesus memanggil itu terjadinya sesuai waktu tindakan memanggil itu terjadi. Bentuk present partisip $\pi \rho о \sigma \kappa \alpha \lambda \varepsilon \sigma a ́ \mu \varepsilon v o \varsigma$ (proskalesamenos) sama waktu dengan dengan kata

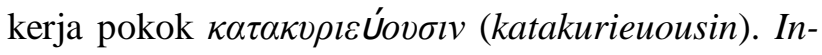
dicative present menunjukkan tindakan memanggil betul-betul terjadi sesuai tensnya yang menunjukkan bahwa tindakan memanggil sedang dilakukan atau dilakukan berulang-ulang dalam waktu kini penulis (Suawa, 2009, p. 146). Yesus memanggil ini benarbenar dilakuan terus-menerus dalam konteks Matius 20:25. Nominative masculine singular memiliki makna bahwa subyek yaitu Yesus yang melakukan tindakan memanggil. Jadi dapat diberi kesimpulan bahwa istilah $\pi \rho о \sigma \kappa \alpha \lambda \varepsilon \sigma a ́ \mu \varepsilon v o \varsigma$ (proskalesamenos) secara gramatikal dalam Matius 20:25 dapat diartikan bahwa Yesus benar-benar melakukan tindakan memanggil.

Istilah "memerintah dengan tangan besi" dalam bahasa Yunani menggunakan kata $\kappa \alpha \tau \alpha \kappa v-$

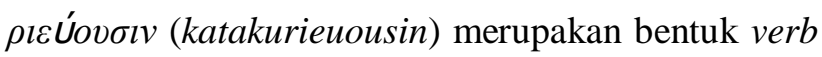
indicative present active 3 rd person plural. Verb Indicative atau kata kerja yang menyatakan kualitas sebuah fakta yang betul-betul terjadi sesuai tensnya (Tindas, 2015, p. 28). Kualitas sebuah fakta disini menunjukkan bahwa "memerintah dengan tangan besi" benar-benar terjadi sesuai tensnya. Present indicative menyatakan bahwa sesuatu pekerjaan sedang dilakukan berulang-ulang. Tindakan memerintah dengan tangan besi benar-benar dilakukan berulang-ulang. Active 3rd person plural menunjukkan bahwa orang ketiga jamak yaitu mereka (pemerintah-pemerintah) yang melakukan tindakan memerintah dengan tangan besi. Jadi dapat diberi kesimpulan

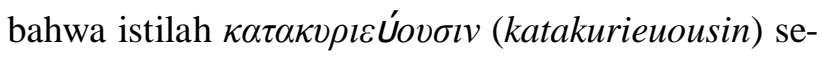
cara gramatikal dalam Matius 20:25 dapat diartikan bahwa tindakan memerintah dengan tangan besi itu benar-benar dilakukan secara terus-menerus oleh pemerintah yang memerintah pada konteks waktu itu. 
Istilah "menjalankan kuasanya dengan keras" dalam bahasa Yunani menggunakan kata $\kappa \alpha \tau \varepsilon$ -

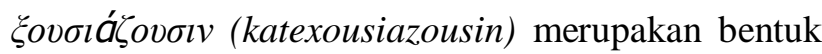
verb indicative present active 3rd person plural. Verb Indicative atau kata kerja yang me-nyatakan kualitas sebuah fakta yang betul-betul terjadi sesuai tensnya (Tindas, 2015, p. 28). Kualitas sebuah fakta disini menunjukkan bahwa "men-jalankan kuasanya dengan keras" benar-benar terjadi sesuai tensnya. Tindakan menjalankan kuasanya dengan keras benar-benar dilakukan berulang-ulang. Active $3 \mathrm{rd}$ person plural menunjukkan bahwa orang ketiga jamak yaitu mereka (pemerintah-pemerintah) yang melakukan tindakan menjalankan kuasanya dengan keras.

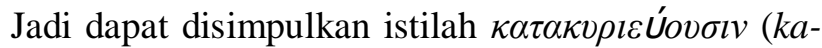
texousiazousin) secara gramatikal dalam Matius 20: 25 dapat diartikan bahwa tindakan menjalankan kuasanya dengan keras itu benar-benar dilakukan secara terus menerus oleh pemerintah yang memerintah pada konteks waktu itu.

Istilah "menjadi pelayanmu" yang digunakan dalam bahasa Yunani menggunakan kata हैं $\tau \alpha l$

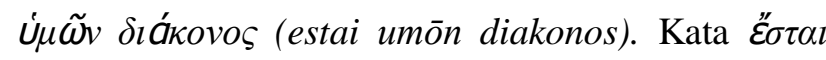
(estai) merupakan bentuk verb indicative future middle 3rd person singular dari akar kata eíuí(eimi). Verb Indicative atau kata kerja yang menyatakan kualitas sebuah fakta yang betul-betul terjadi sesuai tensnya (Tindas, 2015, p. 28). Kualitas sebuah fakta disini menunjukkan bahwa "menjadi pelayanmu" benar-benar terjadi sesuai tensnya, yakni berbentuk future indicative. Bentuk future indicative menyatakan bahwa menunjukkan bahwa sesuatu akan dikerjakan atau akan terjadi (Tindas, 2006, p. 8). Tindakan menjadi pelayanmu benar-benar akan dikerjakan atau akan terjadi. Middle merupakan tindakan reflektif, yang berbalik pada dirinya. 3rd person singular menunjuk kepada orang ketiga tunggal yaitu "dia" atau "nya." Jadi dapat diberi kesimpulan bahwa istilah है $\sigma \tau \alpha$ (estai) secara gramatikal dalam Matius 20:26 jika dihubungkan dengan $\delta$ á́kovos (diakonos) dapat diartikan bahwa membuat dirinya sendiri akan menjadi pelayan.
Istilah "menjadi hambamu" yang digunakan

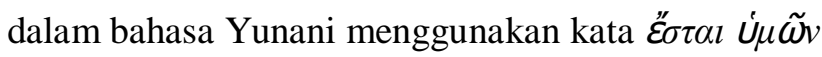

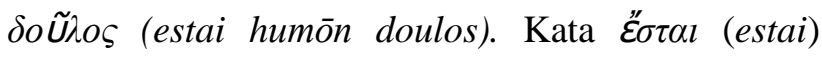
merupakan bentuk verb indicative future middle $3 \mathrm{rd}$ person singular címí(eimi). Verb Indicative atau kata kerja yang menyatakan kualitas sebuah fakta yang betul-betul terjadi. Kualitas sebuah fakta disini menunjukkan bahwa "menjadi hambamu" terjadinya sesuai dengan tensnya future indicative, dimaknai akan dikerjakan atau akan terjadi. Tindakan menjadi hambamu benar-benar akan dikerjakan atau akan terjadi. Middle menunjuk kepada dirinya sendiri. Jadi dapat diberi kesimpulan bahwa istilah हैo $\sigma \alpha l$ (estai) secara gramatikal dalam Matius 20:26 jika dihubungkan dengan $\delta o \tilde{\text { Ũ } o \varsigma ~(d o u l o s) ~ d a p a t ~ d i a r t i k a n ~ b a h w a ~ m e m-~}$ buat dirinya sendiri akan menjadi hamba.

Istilah "untuk melayani" yang digunakan dalam bahasa Yunani menggunakan kata $\delta \imath \alpha \kappa o v \tilde{\eta} \sigma \alpha \iota$ (diakonēsai) merupakan bentuk verb infinitive aorist

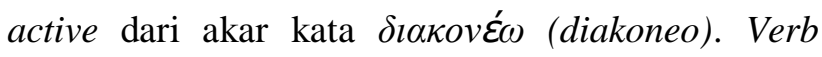
infinitive (kata kerja infinitif) adalah kata kerja dan kata benda, yang dapat berupa perintah, tujuan, hasil suatu tindakan, dan obyek tidak langsung (Tindas,

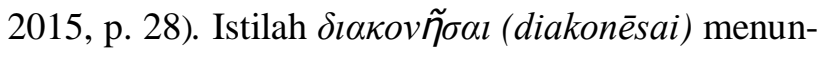
jukkan kata kerja yang berupa tujuan yaitu untuk melayani. Infinitive aorist menunjukkan bahwa tujuan tindakan untuk melayani pernah terjadi atau pernah dilakukan (lampau selesai) karena dalam kalimat "sama seperti Anak Manusia datang bukan untuk dilayani, melainkan untuk melayani dan untuk memberikan nyawa-Nya menjadi tebusan bagi banyak orang," menjelaskan bahwa Anak Manusia memiliki tujuan untuk melakukan tindakan untuk melayani. Voice aktif menunjuk kepada alat (orang atau benda) yang melakukan tindakan, menjadi subjek kata kerja (Margianto, 2008), p. 3), menunjuk kepada Anak Manusia yang bertujuan melakukan tindakan melayani. Jadi dapat diberi kesimpulan bahwa

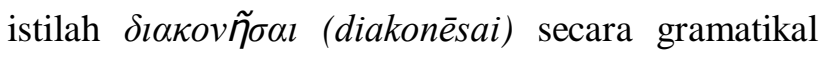
dalam Matius 20:28 dapat diartikan bahwa Anak Manusia datang dengan tujuan untuk melakukan tindakan melayani. 
Istilah "memberikan nyawa-Nya" yang digunakan dalam bahasa Yunani menggunakan kata

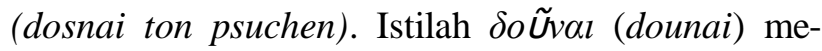
rupakan bentuk verb infinitive aorist active dari akar kata $\delta \delta \delta \omega \mu$ (didomi). Verb infinitive adalah kata kerja infinitif. Istilah $\delta o \tilde{v} \alpha \alpha$ (dounai) menunjukkan kata kerja yang berupa tujuan yaitu untuk "memberikan" nyawa-Nya. Infinitive aorist menunjukkan bahwa tujuan tindakan untuk memberikan nyawa pernah terjadi atau pernah dilakukan (lampau selesai) karena dalam kalimat "sama seperti Anak Manusia datang bukan untuk dilayani, melainkan untuk melayani dan untuk memberikan nyawa-Nya menjadi tebusan bagi banyak orang." menjelaskan bahwa Anak Manusia memiliki tujuan untuk melakukan tindakan untuk memberikan nyawa. Voice aktif menunjuk kepada alat (orang atau benda) yang melakukan tindakan, menjadi subjek kata kerja (Margianto, 2008, p. 3), menunjuk kepada Anak Manusia yang bertujuan melakukan tindakan untuk memberikan nyawa. Jadi dapat diberi kesimpulan bahwa istilah $\delta o \tilde{v} \alpha l$ (dounai) secara gramatikal dalam Matius 20:28 dapat diartikan bahwa Anak Manusia datang dengan tujuan untuk melakukan tindakan "memberikan" nyawa.

\section{Historikal}

Analisis historikal yang dibahas penulis mencakup istilah: memanggil (proskalesamenos), tangan besi (katakurieuousin), dengan keras (katexousiazousin), menjadi pelayanmu (estai humōn diakonos), menjadi hambamu (estai humōn doulos), untuk melayani (diakonēsai), memberikan nyawa-Nya (dosnai ton psuchen).

Istilah $\pi \rho о \sigma \kappa \alpha \lambda \varepsilon \sigma a ́ \mu \varepsilon v o \varsigma$ (proskalesamenos)

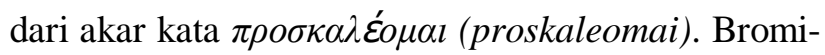
ley (1992, p. 397) menjelaskan sejarah penggunaan

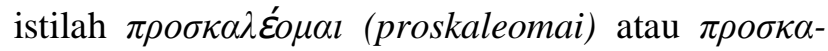
$\lambda \varepsilon \dot{c} \omega$ (proskaleo) secara historikal dalam Matius 20: 25 menunjuk pada seseorang yang memanggil orang lain dan Kristus telah menjadi contoh untuk memenuhi panggilan Ilahi sebagai Penebus yang diurapi (Kristus).
Istilah "tangan besi" yang dalam bahasa $\mathrm{Yu}$ -

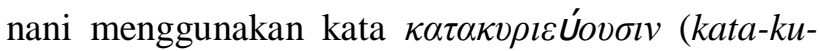

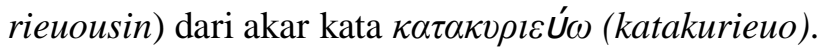

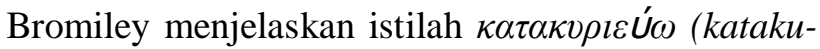
rieuo) digunakan terkait dengan konsep ketuhanan secara historis menggabungkan dua unsur yakni kekuasaan dan otoritas. Manusia adalah ciptaan Tuhan yang memiliki kekuasaan mutlak, dengan otoritasNya Allah juga telah menyatakan anugerah-Nya kepada manusia untuk membebaskan manusia dari perbudakan dosa (Bromiley, 1992, p. 486). Jadi jelaslah

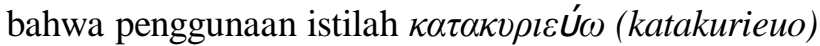
secara historikal dalam Matius 20:25 menunjuk pada memerintah dengan penuh kekuasaan dan otoritas dalam bentuk mutlak.

Istilah "dengan keras" dalam bahasa Yunani

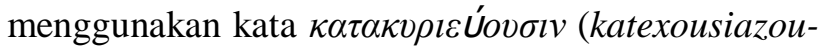

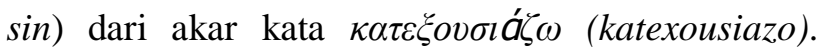
Bromiley (1992, p. 240) menjelaskan sejarah peng-

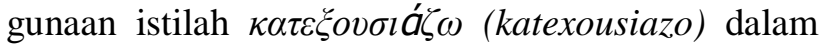
Matius 20:25 menunjuk pada pelaksanaan kekuasaan politik tetapi dengan implikasi paksaan atau penindasan.

Istilah "menjadi pelayanmu" dalam bahasa

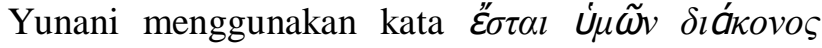
(estai umōn diakonos). Zodhiates (1999, p. 124) menjelaskan penggunaan istilah $\delta$ lákovos (diakonos) secara historikal dalam Matius 20:26 menunjuk pada menjadi pelayan atau orang yang melayani.

Istilah "menjadi hambamu" dalam bahasa

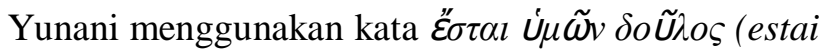
umōn doulos). Bromiley menjelaskan penggunaan istilah $\delta o \tilde{u} \lambda o \varsigma$ (doulos) atau budak sangat bergantung pada tuannya. Orang-orang Yunani di masa lalu sebelum kemerdekaaan sangat membutuhkan kemerdekaan politik (perbudakan). Plato sebagai ahli hukum dizamanya mengijinkan manusia hanya boleh diperbudak oleh hukum, artinya dikendalikan oleh hukum (Bromiley, 1992, 182). Jadi jelaslah bahwa penggunaan istilah $\delta o \tilde{\imath} \lambda o \varsigma$ (doulos) secara historikal dalam Matius 20:27 menunjuk pada men- 
jadi budak yang hidup untuk menghamba atau mengabdi kepada tuannya.

Istilah "untuk melayani" dalam bahasa Yu-

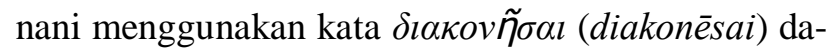

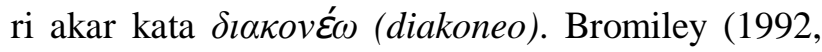

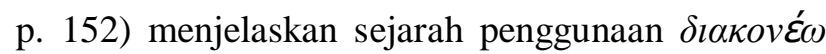
(diakoneo) dalam Matius 20:28 menunjuk pada seseorang yang merawat, pelayan yang menunggu di meja untuk melayani, atau berkorban untuk menolong orang lain.

Istilah "memberikan" dalam bahasa Yunani

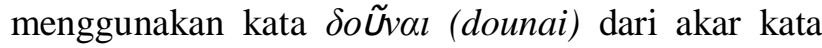
$\delta ' \delta \omega \mu$ (didomi). Bromiley (1992, p. 166) menjelaskan sejarah penggunaan istilah $\delta$ oũvol (dounai) dalam Matius 20:28 menunjuk pada pemberian atau memberikan yang dilakukan dari pihak Tuhan.

\section{Analisis Teologikal}

Analisis teologi adalah kajian analogi Alkitab, yang menyelidiki bagaimana tulisan Alkitab menafsirkan dirinya sendiri (scripture interprets scripture) menjadi titik tolak dalam observasi teologis. Teologi harus secara obyektif berasal dari naskah Alkitab. Teks Matius 20:25-28 merupakan perintah Tuhan Yesus kepada murid-murid-Nya untuk meneladani diri-Nya menjadi seorang pe-mimpin yang mau melayani dan berhati hamba. Matius 20:25-28 mengungkapkan bahwa Tuhan Yesus sedang berbicara kepada murid-murid-Nya. Kepemimpinan sekuler lebih mengedepankan kekuasaan untuk maksudmaksud pribadi, namun kepemimpinan rohani tidaklah demikian, sebab standar kepemimpinan dibangun di atas dasar prinsip-prinsip rohani (Kerajaan Allah). Jadi melakukan kepemimpinan rohani lebih kepada kesediaan untuk melayani sebagai hamba Tuhan bukan sebagai pemimpin yang menunjukkan kekuasaan yang mengekang atau mengintimidasi.

Istilah hamba (Yunani: diakonos) dipakai sebagai istilah yang menunjukkan tugas pelayanan Kristen dan setiap pelayan harus mengingat arti sebenarnya dari kata itu. Ditegaskan bahwa dasar dari prinsip kepemimpinan Kristen adalah teladan dan kematian Tuhan Yesus. ia memberikan nyawa-Nya dan menjadi tebusan bagi banyak orang.

\section{Analisis Homiletikal}

Analisis homiletikal adalah analisis yang dikerjakan bertujuan untuk mengkhotbahkan teks Alkitab, dalam hal ini terambil dari Matius 20:25-28. Sasmoko (2008, p. 252) menulis "Analisis homiletis adalah kajian tentang bagaimana hasil eksegesis naskah Alkitab dapat diteruskan kepada dan men-dapat respon dari audiens atau Gereja”. Adapun hasil analisis homiletikal dari Matius 20:25-28 terkait dengan kepemimpinan hamba Tuhan adalah sebagai berikut: komunikatif (ay. 25), tegas (ay. 25), lemah lembut (ay. 26), rendah hati (ay. 26-27), melayani (ay. 28), rela berkorban (ay. 28).

Komunikatif dalam ayat 25 'Tetapi Yesus memanggil mereka ...." Nixon (1999, p. 106) menuliskan bahwa secara khusus Yesus memanggil murid-murid. Panggilan Yesus begitu komunikatif dilatar belakangi oleh "kebanyakan masyarakat kekuasaan dicari untuk maksud-maksud pribadi." Jadi kepemimpinan Yesus dalam memanggil untuk melayani terlihat komunikatif (begitu jelas dan bukan suatu kekuasaan pribadi bagi murid-murid). Komunikatif menjadi unsur karakter dan kompetensi utama dalam kepemimpinan hamba Tuhan.

Tegas dalam ayat 25 ". . Kamu tahu, bahwa pemerintah-pemerintah bangsa-bangsa memerintah rakyatnya dengan tangan besi dan pembesar-pembesar menjalankan kuasanya dengan keras atas mereka." Teks di atas menegaskan bahwa Yesus memahami bahwa dalam gaya kepemimpinan sekuler tegas adanya yang ditunjukkan dengan memerintah dengan tangan besi dan kuasa yang keras. Yesus tidak bermaksud agar murid-murid memerintah dengan tangan besi dan kuasa yang keras, namun lebih kepada ketegasan yang dimiliki oleh pemimpin sekuler.

Lemah lembut dalam ayat 26 "Tidaklah demikian di antara kamu." Stamps (2008, p. 1545) memberikan komentar bahwa konsep kepemimpinan sekuler lebih mengedepankan kekuasaan, kedudukan untuk memerintah dan menguasai. Nixon (1999, p. 
106) selanjutnya menjelaskan ayat 26 bahwa "Tidaklah demikian di antara kamu: Ukuran kerajaan itu sangat berbeda. Kebesaran ditunjukkan dalam pelayanan". Ayat 25 menjelaskan bahwa pemimpin sekuler memimpin dengan tangan besi dan kuasa yang keras, namun murid yang dipanggil untuk melayani, Yesus memimpin murid-murid tersebut dengan gaya yang sangat berbeda. Yesus tidak memimpin dengan tangan besi atau keras tetapi lemah lembut. Memimpin dalam konsep Yesus bukan untuk menjadi berkuasa, sehingga harus dengan kekerasan melainkan untuk melayani itulah sebabnya harus dengan lemah lembut.

Rendah hati dalam ayat 26-27 "Barangsiapa ingin menjadi besar di antara kamu, hendaklah ia menjadi pelayanmu, ... menjadi hambamu." Teks tersebut dipahami oleh Kent (2008, p. 117) lebih kepada "kesediaan untuk melayani merupakan tanda kebesaran rohani". Nixon (1999, p. 106) selanjutnya menuliskan "Istilah hamba (diakonos) dipakai sebagai istilah yang paling umum untuk tugas pelayanan Kristen dalam Perjanjian Baru dan setiap 'pelayan' harus mengingat arti sebenarnya dari kata itu". Jadi filosofi kepemimpinan yang ditanamkan oleh Yesus kepada murid-murid lebih kepada kerendahan hati yakni menjadi hamba, menjadi hamba bukan berarti menjadi rendah melainkan menunjukkan adanya kebesaran rohani.

Melayani dalam ayat 28 "sama seperti Anak Manusia datang bukan untuk dilayani, melainkan untuk melayani ...” Kent (2008, p. 117) menjelaskan Kristus sebagai Anak Allah menyerahkan nyawa-Nya di Kalvari kepada Allah untuk menjadi tebusan. Yesus Kristus yang disebut Anak Manusia adalah pemimpin yang melayani bukan pemimpin yang berkuasa secara sekuler. Sikap Yesus sebagai pemimpin yang melayani harus dijadikan teladan oleh murid-murid dalam pelayanan.

Rela berkorban dalam ayat 28 "... untuk memberikan nyawa-Nya menjadi tebusan bagi banyak orang." Yesus menjadi tebusan dikomentari oleh Nixon (1999, p. 106) sebagai tindakan pembebasan yang mahal dari pribadi yang benar. Penebus- an Kristus merupakan tindakan pembebasan dari hukuman yang harus dialami oleh manusia sebagai akibat dari dosa. Stamps (2008, p. 1546) selanjutnya menjelaskan bahwa tebusan Yesus yang ditunjukkan melalui kematian-Nya merupakan harga yang harus dibayar untuk membebaskan manusia dari kuasa akibat dosa yakni maut atau neraka. Luasnya atau jangkauan penebusan Kristus dijelaskan oleh Kent (2008, p. 117) diperuntukkan bagi banyak orang artinya tidak terbatas karena diberikan kepada setiap orang yang menerima penebusan-Nya. Yesus Kristus rela berkorban yang ditunjukkan melalui kematian-Nya di atas kayu salib, diperun-tukkan kepada banyak orang, hal ini tidak menunjukkan pada pembatasan tertentu atau jumlah tertentu, namun lebih kepada setiap orang atau siapa saja yang mau menerima atau mengakui kematian-Nya. Jadi melalui analisis homiletikal diketahui bahwa kepemimpinan hamba Tuhan dapat diwujudkan bila memperhatikan perintah dan mencontoh kepemimpinan Yesus yang komunikatif, tegas, lemah lembut, rendah hati, melayani, rela berkorban.

\section{KESIMPULAN}

Berdasarkan hasil penelitian yang telah dilakukan, maka diperoleh beberapa kesimpulan. Pertama, peneliti setelah melakukan kajian teori baik secara etimologi, pengertian para pakar maupun kajian Alkitab, maka mendefinisikan kepemimpinan hamba Tuhan adalah tindakan dalam mempengaruhi atau memberikan keteladan dari setiap pelayan Tuhan untuk melakukan kehendak Allah. Kedua, ciri dari kepemimpinan hamba Tuhan menurut Matius 20:25-28, dengan ciri-ciri: komunikatif (ay. 25), tegas (ay. 25), lemah lembut (ay. 26), rendah hati (ay. 26-27), melayani (ay. 28), rela berkorban (ay. 28). Ketiga, analisis sintaktikal yang terlihat melalui hubungan frasa-frasa dengan tema proposisi, hubungan klausa-klausa dengan tema proposisi, hubungan kalimat-kalimat dengan tema proposisi memberikan dukungan terhadap teks Matius 20:25-28 adalah tepat terkait dengan tema proposisi kepemimpinan hamba Tuhan. Keempat, analisis verbal yang dije- 
laskan secara leksikal, gramatikal dan historikal melalui berbagai istilah memperkuat ciri dari kepemimpinan hamba Tuhan. Istilah "memanggil (proskalesamenos)" mewakili ciri dari komunikatif. Istilah "tangan besi (katakurieuousin)" mewakili ciri dari tegas. Istilah "dengan keras (kate-ousiazousin)" mewakili ciri dari lemah lembut. Istilah "menjadi pe-

\section{DAFTAR RUJUKAN}

Adler, Nancy dan Allison Gundersen. 2008. International Dimensions of Organizational Behavior. $5^{\text {th }}$ Edition. US: Thomson SouthWestern.

Bauer's, Walter; William F. Arndt, F. Wilbur Gingrich. 1958. A Greek - English Lexicon of the New Testament. Chicago: The University of Chicago Press.

BibleWorks8, LLC. 3800 Colley Avenue \#6158 Norfolk, VA 23508

Bromiley, Geoffrey W. Theological Dictionary of the New Testament. 1992. Diedit oleh Gerhard Kittel and Gerhard Friedrich. Grand Rapids, Michigan: William B. Eerdmans Publishing Company.

Crampton, W. Gary. 2000. The Bible: God's Word (Verbum Dei). Terjemahan oleh R. B. G. Steve Hendra. Surabaya: Momentum.

Dana, H. E. \& Julius R. Mantey. 1957. A Manual Grammar Of The Greek New Testament. Toronto: The Macmillan Company.

Douglas, J.D. 1984. New Bible Dictionary. Second Edition. Leicester, England: Inter-Varsity Press.

Enns, Paul. 2003. The Moody Handbook of Theology. Terjemahan oleh Rahmiati Tanudjaja. Disunting oleh Nicholas Kurniawan, Sri Lestarini, Elisabeth Yuliasari. Malang: Literatur SAAT.

Hayes, John H. \& Holladay, Carl R. 2006. Pedoman Penafsiran Alkitab. Jakarta: BPK Gunung Mulia.

Kaiser, Walter C. Jr. 1988. Toward An Exegetical Theology: Biblical Exegesis For Preaching layanmu (estai humōn diakonos)" mewakili ciri dari rendah hati. Istilah "menjadi hambamu (estai humōn doulos)" mewakili ciri dari melayani. Istilah "untuk melayani (diakonēsai)" mewakili ciri dari rela. Istilah "memberikan nyawa-Nya (dosnai ton psuchen)" mewakili ciri dari berkorban.

And Teaching. Grand Rapids, Michigan: Baker Book House.

Kamus Besar Bahasa Indonesia (KBBI). Kamus versi online/daring (dalam jaringan). 2019. http://pusatbahasa.kemdiknas.go.id/kbbi/ Diakses tanggal 12 Januari 2019.

Katarina \& Krido Siswanto. "Keteladan Kepemimpinan Yesus dan Implikasinya Bagi Kepemimpinan Gereja Pada Masa Kini." Evangelikal: Jurnal Teologi Injili dan Pembinaan Warga Jemaat, 2 (2): 87-98.

Kent, Homer A. 2008. Tafsiran Alkitab Wycliffe. Volume 3. Terjemahan oleh Gandum Mas. Disunting oleh Everett F. Harrison. Cetakan Ketiga. Malang: Gandum Mas.

Kouzes, James M. dan Barry Z. Posner. 1997. Kredibilitas: Bagaimana Para Pemimpin Mendapatkan dan Kehilangan Kredibilitas, Mengapa Orang Menuntutnya. Terjemahan oleh Anton Adiwiyoto. Jakarta: Professional Books.

Manz, Charles C. 2005. Leadership Wisdom of Jesus. San Francisco: Berrett Koehler Publication.

Margianto, Yoppi. 2008. Belajar Sendiri Bahasa Yunani Berdasarkan Injil Yohanes. Yogyakarta: Andi Offset.

Mawikere, Marde Christian Stenly. "Efektivitas, Efisien dan Kesehatan Hubungan Organisasi Pelayanan dalam Kepemimpinan Kristen.” Evangelikal: Jurnal Teologi Injili dan Pembinaan Warga Jemaat, 2 (1): 50-56.

Munroe, Myles. 1993. Becoming A Leader. Lanham, MD: Pneuma Life. 
Nixon, R. E. Tafsiran Alkitab Masa Kini. 1999. Jilid 3. Terjemahan oleh H. P. Nasution. Cetakan Kesebelas. Jakarta: Yayasan Komunikasi Bina Kasih/OMF.

Packer, J. I.; Merrill C. Tenney, William White, Jr. 1995. Dunia Perjanjian Baru. Terjemahan oleh Johan C. Pandelaki. Cetakan Kedua. Surabaya: YAKIN.

Pena, Tim Prima. Kamus Besar Bahasa Indonesia. Jakarta: Gitamedia Press, t. t.

Ronda, Daniel. "Kepemimpinan Kristen di Era Disrupsi Teknologi." Evangelikal: Jurnal Teologi Injili dan Pembinaan Warga Jemaat, 3 (1): 1-8.

Ryrie, Charles C. 1991. Teologi Dasar. Jilid 1. Terjemahan oleh Yan Antoni. Disunting oleh Antoni Stevens, Hariyono, Xavier Q. P. Yogyakarta: ANDI.

Sasmoko. 2008. Metode Penelitian. Disunting oleh Dewi Anggriyani. Jakarta: Harvest International Theological Seminary.

Stamps, Donald C. (Editor Umum). 2008. Alkitab Penuntun Hidup Berkelimpahan. Terjemahan oleh Nugroho Hananiel. Disunting oleh
Bertha Gaspersz. Cetakan Ketiga belas. Malang: Gandum Mas.

Stuart, Douglas. 1994. Eksegesa Perjanjian Lama. Malang: Gandum Mas.

Suawa, Ferdinan K. 2009. Memahami Gramatika Dasar Bahasa Yunani Koine. Bandung: Yayasan Kalam Hidup.

Tindas, Arnold. 2006. Pelajaran Dasar Bahasa Yunani Perjanjian Baru. Jakarta: Harvest International Theological Seminary.

Tindas, Arnold. 2015. Eksegesis Alkitab. Jakarta: Harvest International Theological Seminary.

Virkler, Henry A. 1993. Hermeneutics: Principles and Processes of Biblical Interpretation. Twelfth Printing. Grand Rapids, Michigan: Baker Book House.

Wofford, Jerry C. 2001. Kepemimpinan Kristen yang Mengubahkan. Yogjakarta: Andi.

Zodhiates, Spiros. 1999. The Complete Word Study New Testament, Bringin The Original Text To Life For A Deeper Understanding. Chattanooga, TN: AMG Publisher. 